УДК 616.34-089.86:621.791]-092:[611.018:001.891.5

DOI 10.11603/2414-4533.2018.2.9230

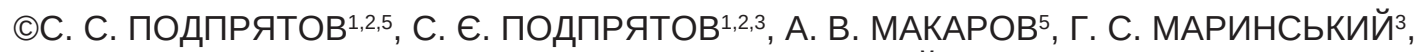
В. А. ТКАЧЕНКО ${ }^{3}$, О. В. ЧЕРНЕЦЬ ${ }^{3}$, Д. В. ТАРНАВСЬКИЙ ${ }^{4}$, К. Г. ЛОПАТКІНА ${ }^{3}$

Київський центр електрозварювальної хірургії та новітніх технологій ${ }^{1}$

Київська міська клінічна лікарня № $1^{2}$

Інститут електрозварювання імені $€$. О. Патона НАН України ${ }^{3}$

Національний університет біоресурсів і природокористування України ${ }^{4}$

Національна медична академія післядипломної освіти імені П. Л. Шупика ${ }^{5}$

\title{
Встановлення первинних вимог до експериментальних засобів дослідження та умов створення електрозварного з'єднання стінок кишечнику
}

\begin{abstract}
Мета роботи: розробити первинні вимоги для передклінічних досліджень зі створення електрозварного з’єднання в міжкишковому анастомозі.

Матеріали і методи. На основі ознак якості та міцності, що були впроваджені для заварювання артерій, сформулювали первинні вимоги до параметрів експериментального випробувального стенда. Джерелом електрозварювальних імпульсів був адаптований клінічний апарат ЕK-300M1. Використовували електрозварювальний пінцет у варіантах пласких електродів та із зубоподібними елементами, затискачі без кремальєри - та з кремальєрою, з підвищеними можливостями стискання. В умовах гострого експерименту на ділянках кишки свині наклали 3 скобкові анастомози діаметром 29 мм, який містив 2 ряди скобок, та по 8 електрозварних кожним з інструментів. Всі анастомози відразу видаляли та досліджували міцність з’єднання та візуальні якості перетворень тканини.

Результати досліджень та їх обговорення. Тиск витоку рідини для скобкового з’єднання склав $(24,0 \pm 1,0)$ мм рт. ст. унаслідок прорізування скоб, а для затискача з можливістю стискання електродами тканини до 2 Н/мм² склав $(18,4 \pm 5,8)$ мм рт. ст., в діапазоні від 9,2 до 26,8 мм рт. ст., для решти інструментів - $(10,6 \pm 7,2)$ мм рт. ст. Температура його електродів перебувала в діапазоні 53-86 ㄷ․ Задовільним визнали проходження електрозварного струму від 1 до 5 А у 65 \% спроб.
\end{abstract}

Ключові слова: електрозварювання; анастомоз; кишка; інструмент; тиск; тканина.

Постановка проблеми і аналіз останніх досліджень та публікацій. Радіочастотне коагуляційне з'єднання - сучасна та ефективна технологія в безшовному перекритті великих судин, проток та структур паренхіматозних органів, при яких відбувається з'єднання їх стінок [1]. Ефективність та привабливість клінічного застосування технології високочастотного електрозварювання біологічних тканин підтверджено в різних галузях хірургії [2].

Неспроможність лінії з'єднання в міжкишковому анастомозі (МА) на сьогодні є актуальною проблемою незалежно від методу його створення [3]. Всі відомі на сьогодні способи створення анастомозу мають ознаки вторинного загоєння $[4,5,6]$. Електрозварювальний спосіб з'єднання стінок кишки $є$ одним із перспективних способів створення принципово нового типу МА [7].

У первинних дослідженнях із вивчення впливу різних режимів подачі електрозварної напруги на живу тканину встановлено, що виважене стиснення тканини $є$ однією з необхідних складових отримання електрозварного з'єднання стінок судин, що мало унікальні характеристики. В цьому ж типі з'єднання встановлено ознаки високочастотного електричного та термічного впливу [8].
Створення безшовного міжкишкового з'єднання вимагає глибокого розуміння змін, що відбуваються під впливом електрозварювальних імпульсів в стінках органа, оскільки відмінна від стінки судини, де зварювання досягає високої міцності [9], морфологічна будова кишки визначає відмінність фізичних характеристик щільності, імпедансу тощо [10].

Відповідне дослідження має грунтуватись на використанні тканин, максимально подібних до тканин людини. Для отримання електрозварного MA (EMA) з необхідними та повторюваними характеристиками важливе забезпечення в лабораторній експериментальній зоні умов, відповідних до подальшого клінічного використання розробленого методу, щоб мати можливість прямого перенесення результатів [11].

Зважаючи на викладене, а також з урахуванням потреби багаторазової перевірки різних параметрів електрозварювання, вирішено розробити медико-технічні умови для проведення лабораторних експериментальних досліджень зі з'єднання стінок кишечнику.

Мета роботи: розробити первинні вимоги для передклінічних досліджень зі створення електрозварного з'єднання в міжкишковому анастомозі. 
Матеріали і методи. На основі дослідження візуальних ознак якості та міцності на розрив електрозварного з'єднання стінок кишки, створеного 3 використанням існуючих електрозварних інструментів та алгоритмів подачі напруги, закладених у режими електрозварювання, що були розроблені і ефективно впроваджені для заварювання артерій - сформулювали первинні вимоги до параметрів експериментального випробувального стенду для проведення лабораторних експериментальних досліджень зі з'єднання стінок кишечника електрозварюванням, яке б мало стабільну перевагу в розривній міцності та герметичності порівняно з апаратним з'єднанням скобками.

Електрозварювальним джерелом живлення і електрозварювальних імпульсів був адаптований до умов експериментів апарат для зварювання живих тканин EK-300M1, дозволений для клінічного використання. Використовували розроблені для нього інструменти виробництва Інституту електрозварювання ім. Є. О. Патона: електрозварювальний пінцет у варіантах пласких поверхонь електродів та пласких із зубоподібними елементами, затискачі без кремальєри та з кремальєрою та підвищеними можливостями стискання.

В умовах гострого експериментального дослідження повнорозмірний ЕМА створювали на ділянках тонкої та товстої кишки свині. Дослідження було комплексним, і проведене на базі ветеринарного факультету Національного університету біоресурсів і природокористування України, з дотриманням Правил використання експериментальних тварин та Етичних принципів експериментів на тваринах (Київ, 2000), що узгоджуються з положеннями Європейської конвенції про захист хребетних тварин, які використовуються для експериментальних та інших наукових цілей. На одній свині породи “Велика біла” масою 45 кг. після виконання лапаротомії наклали послідовно 3 скобкових МА з застосуванням хірургічного механічного зшиваючого пристрою діаметром 29 мм, який містив 2 ряди скобок. Також створили по 8 ЕМА кожним з інструментів. Всі створені МА відразу видаляли та досліджували.

Операцію виконували після премедикації, під ендотрахеальним наркозом. Тварині у вольєрі здійснили премедикацію з використанням препарату Комбістрес. Після досягнення седації тварину переносли в операційну та ввели в наркоз. Після закінчення програми експерименту тварину, не виводячи з наркозу, умертвили шляхом введення смертельної дози натрію тіопенталу.

Інструментами для електрозварювання захоплювали протилежні стінки кишки з зовнішньої, серозної поверхні, в проміжках між накладеними раніше трьома серозно-м'язовими утримуючими лігатурами. Стінки відрізків кишки зводили на одному рівні, максимально затискали протягом 60 с, після чого подавали електрозварювальні імпульси в автоматичному режимі. Після зварювання електроди розводили і перевстановлювали поруч з попередньою точкою зварювання, з кроком відповідно до межі електрозварних змін. Після закінчення зварювання по колу кишки видаляли лігатури.

Випробовування на максимальну міцність здійснювали введенням ізотонічного розчину натрію хлориду, повільно підвищуючи тиск в просвіті відрізку кишки до настання розриву з'єднання. Порівнювали отримані значення для ЕМА з попередньо визначеним рівнем міцності скобкового МА. Вимірювання тиску здійснювали за допомогою приєднаного до системи введення рідини електронного манометра DPG8000 M4026/1203 фірми Omega, США, сертифікованого за ISO 9001.

Окрім видимих перетворень у тканинах, дистанційно контролювали температуру тканини під час зварювання з використанням професійного безконтактного інфрачервоного пірометра Benetech GM 1850, сертифікованого за ISO 9001.

Візуально якість з'єднання оцінювали за характеристиками рівномірності, набуття полімерного вигляду та відсутності термічного некрозу.

Результати досліджень та їх обговорення. 3 метою подальшого порівняння створили та виміряли розривний тиск для апаратного скобкового MA: його величина, при якій порушувалася герметичність в наслідок прорізування скоб, склала $(24,0 \pm 1,0)$ мм рт. ст.

Дослідили параметри електрозварювального інструмента, розробленого для перекриття судин. Вимірявши значення тиску між електродами, використаного в дослідженні електрозварювального інструменту, встановили, що при максимальному стисканні електрозварювального пінцета тиск пласких поверхонь електродів склав 0,1-0,3 H/Mм², залежно від довжини пінцету, а тиск зубчастих елементів на кінцях браншів - 1,8 Н/ мм² $^{2}$ при цьо-

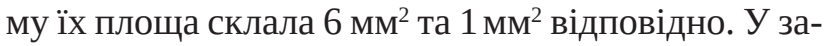
тискачі без кремальєри тиск між електродами становив $0,25-0,75$ H/: м² $^{2}$ а затискача 3 кремальєрою та підвищеними можливостями стискання (3АТ2) 1-2 H/мм², при цьому їх площа склала 40 мм² та

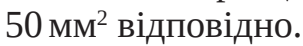

У дослідженні можливості отримання з’єднання обрали спосіб складання стінок кишки “серозна оболонка до серозної”, з огляду на застосування подібного способу в скобковому пристрої 
для створення анастомозу. Ззовні краї зведених відрізків кишки захоплювали електродами обраного інструмента, симетрично зіставляли шари стінки, після чого остаточно фіксували тканину затисканням інструмента. Крізь остаточно фіксовані тканини натисканням педалі електрозварювального апарата подавали електрозварювальний імпульс в обраному режимі.

Дозування електрозварювального впливу здійснювали або в індивідуально керованому (“ручному”) або в автоматичному режимі. При роботі в режимах “різання”, “коагуляція” та “зажим/ ручне зварювання” тривалість подачі напруги на електроди відповідала тривалості стиснення педалі дослідником. При роботі в автоматичному режимі після натискання дослідником педалі напругу подавали автоматично, тривалість подавання електрозварного імпульсу відповідала попередньо до закладеного в електрозварювальний апарат алгоритму та установкам обраного режиму “зварювання”.

При створенні електрозварного з'єднання намагалися досягти в тканинах біоімітатора таких змін, які були визначені як показники якості при електрозварному перекритті судин великого діаметру: структурна однорідність з'єднання, відсутність обвуглення, обмежений ступінь та поширення термічного впливу поза електродами, бурштиново-полімерний вигляд лінії з'єднання та їі щільно-еластична консистенція.

Відзначили, що при застосуванні інструмента 3АТ2 у позиції максимального стиснення якість перетворень у тканинах була значно ближчою до покажчиків якості електрозварних змін у тканинах. Порівняно з іншими інструментами була досягнута відсутність обвуглення, значно менший ступінь термічного впливу поза електродами в автоматичному режимі. Структурну однорідність 3'єднання при застосуванні 3АТ2 досягнуто в 57,5 \% спроб порівняно з 45 \% іншими інструментами, бурштиново-полімерний вигляд лінії з'єднання та її щільно-еластична консистенція у 47,5 \% та 22,5 \% відповідно.

3'єднання відрізків стінок кишки, яке не руйнувалося при зніманні з інструменту, спостерігали в 67,5 \% спроб із ЗАТ2 та 52,5 \% у спробах з іншими інструментами. Міцність з'єднання на розрив для 3АТ2 склала $(18,4 \pm 5,8)$ мм рт. ст., в діапазоні від 9,2 до 26,8 мм рт. ст., для решти інструментів $(10,6 \pm 7,2)$ мм рт. ст.

При цьому встановили, що найвищі значення міцності електрозварного з'єднання досягнено при використанні індивідуально керованого, переривчастого подавання імпульсу на 3АТ2.
В автоматичному режимі в 3АТ2 спостерігали нестабільність перебігу електрозварного імпульсу: у 27,5 \% через недосягнення базових параметрів в тканині кишки (пінцети та затискач без кремальєри), у 7,5 \% спостерігали коротке замикання електричного ланцюга через нестабільність електродів в інструменті (затискач без кремальєри). У решти 65 \% максимальна сила струму в другій фазі коливалася в межах від 1 до 5 А. При цьому в $10 \%$ спостерігали епізоди формування містків струму в процесі електрозварювання через оточуючі тканини поблизу електродів, які були стиснені елементами конструкції 3АТ2.

Встановлено пряму залежність зростання температури тканини від параметрів зростання струму та його тривалості. Температура тканини біля електродів перебувала в діапазоні 53-86 ${ }^{\circ} \mathrm{C}$ та $22-$ $55^{\circ} \mathrm{C}$.

Висновки. 1. Застосування параметрів, закладених у судинний електрозварний інструмент та відповідні програми електрозварювання, не забезпечує можливості стабільно отримувати показники тиску розриву міжкишкового анастомозу, прийнятні для клінічної практики.

2. При пошуку оптимальних режимів створення електрозварного анастомозу кишечнику слід проводити дослідження впливу на якість отриманого з'єднання попереднього стискання тканини кишки до 3 H/Mм².

Перспективи подальших досліджень. Бажані переважаюча міцність на розрив герметичного електрозварного з'єднання стінок кишки досягнуто в окремих спробах, але стабільність цього рівня не забезпечується ані властивостями існуючих електрозварних інструментів, ані алгоритмами подачі напруги, закладеними в режими електрозварювання, що були розроблені і ефективно впроваджені для заварювання артерій.

Досліджені показники створили основу для формулювання вимог до базових параметрів експериментів зі створення та відпрацювання електрозварного з'єднання тканин кишки в МА з переважаючою шовні МА міцністю.

Станини для фіксації електродів повинні бути відкритого типу, мати відповідність до робочої частини майбутнього спеціалізованого клінічного (модельного) інструменту і відповідати способам застосування - тому передбачати два варіанти електродів: поздовжний та циліндричний, тканина на яких має бути розправлена. Для цього довжина поздовжних електродів повинна сягати 100 мм, ширина - 5 мм, а діаметр ци- 
ліндричного електроду має бути в типорозмірах 25 мм, 29 мм та 31 мм, відповідно до варіації діаметра кишки.

Невідповідність параметрів, закладених у алгоритм автоматичного формування електрозварного імпульсу, особливостям стінки кишки вимагає підключення електродів через дроти всереди- ні тканин до діагностичних електричних систем 3 метою корекції параметрів водночас з підвищеним стисненням.

Вивчення на майбутньому стенді комбінованої ефективності зміни параметрів впливу на тканину приведе до формулювання нових спеціалізованих технологічних умов для створення ЕМА.

\section{СПИСОК ЛІТЕРАТУРИ.}

1. Radiofrequency vessel-sealing system versus the clampcrushing technique in liver transection: results of a prospective randomized study on 100 consecutive patients / A. Muratore, A. Mellano, G. Tarantino [et al.] // HPB: The Official Journal of the International Hepato Pancreato Biliary Association. - 2014. Vol. 16 (8). - P. 707-712. doi:10.1111/hpb.12207.

2. Linchevskyy $O$. Lung sealing using the tissue-welding technology in spontaneous pneumothorax / O. Linchevskyy, A. Makarov, V. Hetman // European Journal of Cardio-thoracic Surgery. - 2010. - Vol. 37. - P. 1126-1128. DOI: 10.1016/j. ejcts.2009.11.01.

3. Stapled versus handsewn methods for colorectal anastomosis surgery / Neutzling, C.B., Lustosa, S.A.S., Proenca, I.M. [et al.]; Matos D. (Ed.) // Cochrane Database Syst. Rev. - 2012. - Vol. 2. DOI: 10.1002/14651858.CD003144.pub2.

4. Davis B. Complications of colorectal anastomoses: leaks, strictures, and bleeding / B. Davis, D. E. Rivadeneira // Surg. Clin. North Am. - 2013. - Vol. 93 (1). - P. 61-87. doi: 10.1016/j. suc.2012.09.014.

5. Compression versus hand-sewn and stapled anastomosis in colorectal surgery: a systematic review and meta-analysis of randomized controlled trials / A. A. Slesser, G. Pellino, O. Shariq

\section{REFERENCES}

1. Muratore, A., Mellano, A., Tarantino, G., Marsanic, P., De Simone, M., \& Di Benedetto, F. (2014). Radiofrequency vessel-sealing system versus the clamp-crushing technique in liver transection: results of a prospective randomized study on 100 consecutive patients. HPB: The Official Journal of the International Hepato Pancreato Biliary Association, 16 (8), 707-712. doi:10.1111/ hpb.12207.

2. Linchevskyy, O., Makarov, A., Hetman, V. (2010). Lung sealing using the tissue-welding technology in spontaneous pneumothorax. European Journal of Cardio-thoracic Surgery 37, 11261128 DOI: 10.1016/j.ejcts.2009.11.01.

3. Neutzling, C.B., Lustosa, S.A.S., Proenca, I.M., da Silva, E.M.K., \& Matos, D. (2012). Stapled versus handsewn methods for colorectal anastomosis surgery. Matos, D. (Ed.). Cochrane Database Syst. Rev. 2. DOI: 10.1002/14651858.CD003144.pub2. 4. Davis, B., \& Rivadeneira, D.E. (2013). Complications of colorectal anastomoses: leaks, strictures, and bleeding. Surg. Clin. North Am., 93 (1), 61-87. doi: 10.1016/j.suc.2012.09.014. 5. Slesser, A.A., Pellino, G., Shariq, O., Cocker, D., Kontovounisios, C., Rasheed, S., \& Tekkis, P.P. (2016). Compression versus hand-sewn and stapled anastomosis in colorectal surgery: a systematic review and meta-analysis of randomized controlled trials. Tech. Coloproctol., 20 (10), 667-676. doi: 10.1007/s10151016-1521 [et al.] // Tech. Coloproctol. - 2016. - Vol. 20 (10). - P. 667-676. doi: 10.1007/s10151-016-1521

6. Tissue adhesives in gastrointestinal anastomosis: a systematic review / K. A. Vakalopoulos, F. Daams, Z. Wu [et al.] // Journal of Surgical Research. - Vol. 180, Issue 2. - P. 290-300 doi: 10.1016/j.jss.2012.12.043.

7. Ho Y.-H. Techniques for colorectal anastomosis / Y.-H. Ho M. A. T. Ashour // World J. Gastroenterol. - 2010. - Vol. 16 (13). P. 1610-1621. doi: 10.3748/wjg.v16.i13.1610

8. Тканевая высокочастотная электросварочная хирургия: атлас / под ред. Б. Є. Патон, О. М. Іванова. - Київ : “Наукова думка”, 2009. - 193 с.

9. Пересічення артерій з використанням автоматичного електрозварювання / С. Є. Подпрятов, О. Є. Швед, Ю. М. Гупало [та ін.] // Клін. хірургія. - 2007. - № 5-6. - С. 55.

10. Electrical Impedance Spectroscopy Study of Biological Tissues / D. A. Dean, T. Ramanathan, D. Machado, R. Sundararajan // Journal of Electrostatics. - 2008. - Vol. 66 (3-4). - P. 165-177. doi:10.1016/j.elstat.2007.11.005.

11. Intraoperative air testing of colorectal anastomoses: a prospective, randomized trial / J. D. Beard, M. L. Nicholson, R. D. Sayers [et al.] // Br. J. Surg. - 1990. - Vol. 77 (10). P. 1095-1097. doi.org/10.1002/bjs.1800771006

6. Vakalopoulos, K.A., Daams, F., Wu, Z., Timmermans, L., Jeekel, J.J., \& Kleinrensink, G.J., van der Ham, A., \& Lange, J.F. Tissue adhesives in gastrointestinal anastomosis: a systematic review. Journal of Surgical Research, 180 (2), 290300. doi: 10.1016/j.jss.2012.12.043.

7. Ho, Y.-H., \& Ashour, M.A.T. (2010). Techniques for colorectal anastomosis. World J. Gastroenterol. 7; 16(13), 1610-1621. doi: 10.3748/wjg.v16.i13.1610

8. Paton, B.E., \& Ivanova, O.M. (2009). Tkanevaya vysokochastotnaya elektrosvarochnaya khirurgiya [The live tissue's high-frequency electric welding surgery]. Kyiv: Naukova Dumka [in Russian].

9. Podpriatov, S.E., Shved, O.E., Hupalo, Yu.M., Podpriatov, S.S., Lebedev, O.V., ... Hichka, S.H. (2007). Peresichennia arterii z vykorystanniam avtomatychnoho elektrozvariuvannia [The arterial crossing by using automatic electric welding]. Klin. khirurhiia - Clinical Surgery, 5-6, 55 [in Ukrainian].

10. Dean, D.A., Ramanathan, T., Machado, D., \& Sundararajan, R. (2008). Electrical Impedance Spectroscopy Study of Biological Tissues. Journal of Electrostatics, 66 (3-4), 165-177. doi:10.1016/j.elstat.2007.11.005.

11. Beard, J.D., Nicholson, M.L., Sayers, R.D., Lloyd, D., \& Everson, N.W. (1990). Intraoperative air testing of colorectal anastomoses: a prospective, randomized trial. Br. J. Surg., 77 (10), 1095-1097. doi.org/10.1002/bjs.1800771006 


\title{
S. S. PODPRIATOV $1,2,5$, S. E. PODPRYATOV ${ }^{1,2,3}$, A. V. MAKAROV ${ }^{5}$, G. S. MARINSKY ${ }^{3}$, V. A. TKACHENKO ${ }^{3}$, O. V. CHERNETS ${ }^{3}$, D. V. TARNAVSKY ${ }^{4}$, K. G. LOPATKINA ${ }^{3}$
}

Clinical Research Centre of Bonding/Welding Surgery and New Surgical Technologies ${ }^{1}$

Kyiv Municipal Hospital Clinic No. $1^{2}$

E. Paton Electric Welding Institute of National Academy of Science ${ }^{3}$

National University of Life and Environmental Sciences of Ukraine ${ }^{4}$

P. Shupyk National Medical Academy of Postgraduate Education ${ }^{5}$

\section{ESTABLISHING THE FIRST REQUIREMENTS IN EXPERIMENTAL EQUIPMENT FOR INVESTIGATIONS AND GREATION CONDITIONS OF ELECTRIC WELDING OF INTESTINAL CONNECTION}

\begin{abstract}
The aim of the work: to develop the primary requirements for pre-clinical studies on the creation of electric welding intestinal connection in anastomosis.

Material and Methods. Based on the quality and strength attributes that were introduced for arterial crossing, the initial requirements in experimental test bench parameters were established. The electric welding source was the adapted clinical EC-300M1 device. Electro-welding tweezers were used in variants of flat electrodes and with tooth-shaped elements, as well as clamps without fixing - and with it, according to increased tissue compression. In acute swine experiment, 3 stapler two-linear $29 \mathrm{~mm}$ diameter anastomoses, and 8 welding ones by every instrument type, were applied. All anastomoses were removed and investigated by burst strength and the visual qualities of tissue transformations.

Results and Discussion. The fluid leakage pressure for stapled connection was (24.0 \pm 1.0$) \mathrm{mm} \mathrm{Hg}$. as a result of cutting the staples, but for clamp with tissue compress ability between electrodes up to $2 \mathrm{~N} / \mathrm{mm}^{2}$ leakage needs $(18.4 \pm 5.8) \mathrm{mm} \mathrm{Hg}$, in the range from 9.2 to $26.8 \mathrm{~mm} \mathrm{Hg}$. For other instruments leakage pressure was $(10.6 \pm 7.2) \mathrm{mmHg}$. The temperature of electrodes was in the range of $53-86^{\circ} \mathrm{C}$. Satisfactory passage of electric current in range from 1 to $5 \mathrm{~A}$ has watch in $65 \%$ of attempts.
\end{abstract}

Key words: electric welding; anastomosis; intestine; instrument; pressure; tissue.

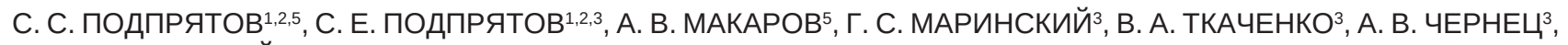
Д. В. ТАРНАВСКИЙ

Киевский городской центр электросварочной хирургии и новых хирургических технологий

Киевская городская клиническая больница № $1^{2}$

Институт электросварки имени Е. О. Патона НАН Украины ${ }^{3}$

Национальный университет биоресурсов и природопользования Украины ${ }^{4}$

Национальная медицинская академия последипломного образования имени П. л. Шупика ${ }^{5}$

\section{ОПРЕДЕЛЕНИЕ ПЕРВОНАЧАЛЬНЫХ ТРЕБОВАНИЙ К ЭКСПЕРИМЕНТАЛЬНЫМ СРЕДСТВАМ ИСС.ЛЕОВАНИЯ И УС.ЛОВИЯМ СОЗДАНИЯ ЭЛЕКТРОСВАРОЧНОГО СОЕДИНЕНИЯ СТЕНОК КИІІЕЧНИКА}

\begin{abstract}
Цель работы: разработать первичные требования для предклинических исследований по созданию электросварочного соединения в межкишечном анастомозе.

Материалы и методы. На основе признаков качества и прочности, которые были внедрены для заваривания артерий, сформулировали первичные требования к параметрам экспериментального испытательного стенда. Источником электросварочных импульсов был адаптированный клинический аппарат ЕК-300М1. Использовали электросварочный пинцет в вариантах плоских электродов и с зубчатыми элементами, зажимы без кремальеры - и с кремальерой, повышенными возможностями сжатия. В условиях острого эксперимента на участках кишки свиньи наложили 3 скобковых анастомоза диаметром 29 мм, содержащий 2 ряда скобок, и по 8 электросварных каждым из инструментов. Все анастомозы сразу удаляли и исследовали прочность соединения и визуальные качества преобразований ткани.

Результаты исследований и их обсуждение. Давление истечения жидкости для скобкового соединения составило $(24,0 \pm 1,0)$ мм рт. ст. вследствие прорезывания скоб. Прочность соединения на разрыв для зажима с возможностью сжатия электродами ткани до 2 H/мм² составила $(18,4 \pm 5,8)$ мм, в диапазоне от 9,2 до 26,8 мм рт. ст., для остальных инструментов $(10,6 \pm 7,2)$ мм рт. ст. Температура его электродов находилась в диапазоне $53-86^{\circ} \mathrm{C}$. Удовлетворительным признали прохождения электросварочного тока от 1 до 5 А в 65 \% проб.
\end{abstract}

Ключевые слова: электросварки; анастомоз; кишка; инструмент; давление; ткань. 